\title{
APPLIED JURISPRUDENCE
}

UDC 346.1

\section{Solovyanenko N.I., Shapsugova M.D. Legal guarranties of freedom of creative activity and entrepreneurship}

\author{
Solovyanenko Nina Ivanovna, \\ PhD, Legal Sciences, Senior Research Fellow, \\ Business and Corporate Law Department, \\ Institute of State and Law RAS \\ Shapsugova Marietta Damirovna \\ PhD, Legal Sciences, Senior Research Fellow, \\ Business and Corporate Law Department, \\ Institute of State and Law RAS
}

\begin{abstract}
The article examines the system of provisions of Russian legislation that guarantee freedom of artistic, scientific, technical and other types of creative activity, as well as the right to access to cultural values. Constitutional guarantees and the corresponding provisions of Federal laws are considered mainly in connection with the postulates of the universal Declaration of Human Rights. The article analyzes the universal constitutional obligations in the sphere of preservation of historical and cultural heritage. A legal link has been established between the freedom of creative activity and the right of citizens to freely use their abilities and property to carry out business activities.

Keywords: sustainable development, freedom of literary, artistic, scientific, technical and other types of creative activity, Russian legislation, Constitutional guarantees, scientific research, museum collections, historical and cultural heritage, protection of intellectual property, entrepreneurial and other economic activities, freedom of contract.
\end{abstract}

Рецензент: Аудкина Ольга Владимировна, кандидат социологических наук, Аоцент. Аонской государственный технический университет (АГТУ), г. Ростов-на-Аону, Факультет “Сервис и туризм", кафедра "Сервис, туризм и индустрия гостеприимства"

Introduction

The Constitution of Russia (article 44) guarantees freedom of literary, artistic, scientific, technical and other types of creative activity and also enshrines the right to participate in cultural life and use cultural institutions, and to have access to cultural values.

The Constitutional provisions are based on the postulates of article 27 of the Universal Declaration of Human Rights[1] and the corresponding rules of article 15 of the International Covenant on Economic, Social and Cultural Rights of 1966, according to which "everyone has the right to participate freely in the cultural life of society, to enjoy the arts, to participate in scientific progress and to enjoy its benefits. States undertake to respect the freedom International journal of Professional Science, №8-2020 
absolutely necessary for scientific research and creative activity" [2]. In the 21st century, the UN ranks creativity and participation in cultural life as the driving forces of sustainable development, calling on States to step up research and promote development-oriented policies that promote creativity and innovation. UNESCO documents note that cultural diversity creates a wide and diverse world that expands the range of choices and nurtures human abilities and values, and is therefore a source of sustainable development for communities, peoples and Nations; cultural development recognizes and promotes social justice and equity within a global ethic, while preserving cultural rights and identity. It also emphasizes the need to integrate culture as a strategic element in national and international development policies, as well as in international development cooperation, including taking into account the UN Millennium Declaration [3].

\section{Results and discussion}

The list of types of creativity in the Constitution of the Russian Federation is open. Creative activity is defined in article 3 of the Law of the Russian Federation of October 9, 1992 N 3612-I "Fundamentals of the legislation of the Russian Federation on culture". In General, creativity is considered in the law as "the creation of cultural values and their interpretation". According to the law, a creative worker creates or interprets cultural values; considers their own creative activity an integral part of their life" [4].

Federal law of August 23, 1996 N 127-FZ" on science and state scientific and technical policy " defines the types of creative activities in the field of science: fundamental, applied and exploratory research, as well as scientific and technical and innovative activities. This Federal law provides for state guarantees of freedom of scientific creativity: state authorities of the Russian Federation guarantee organizations and citizens freedom of creativity in the field of scientific and (or) scientific and technical activities and the right to choose directions and methods of scientific research and experimental development; recognize the right to reasonable risk in scientific and (or) scientific and technical activities (article 3) [5].

The freedom of cultural self-realization of the individual, scientific creativity, may be restricted by public authorities. Restrictions under article 55 of the Constitution must be based on Federal law and only to the extent necessary to protect the foundations of the constitutional order, morals, health, rights and legitimate interests of others, and to ensure national defense and state security. For example, state and administrative bodies and local self-government bodies do not interfere in the creative activities of citizens, except in cases when such activities 
lead to propaganda of war, violence and cruelty, racial, national, religious, class and other exclusivity or intolerance, pornography( article 31).

Enshrined in the Constitution the right of everyone to participate in cultural life and use cultural institutions, access to cultural values associated with the legislative recognition of the fundamental role of culture in development and self-realization, humanization of society and the preservation of national identity of peoples, the approval of their dignity. The right of citizens to participate in cultural life includes such rights as the use of cultural institutions, access to cultural property, and access to state libraries, museums, archives, and other collections in all fields of cultural activity (art. 12). These rights of citizens correspond to the state's obligations to ensure that cultural activities, cultural values and goods are accessible to the public, for example, to preserve the basic services of public libraries free of charge for the population. The state also has a special duty to exercise its cultural protectionism (patronage) towards the least economically and socially protected strata and groups of the population. For example, persons under the age of eighteen are guaranteed the right to visit museums free of charge once a month. Among the principles of state policy in the field of cinematography outlined in the Federal law of 22.08. 1996 N 126-FZ " On state support of cinematography of the Russian Federation "[6], specifies the creation of conditions for the population to access works of cinematography (article 1). Federal law of 26.05. 1996 N 54-FZ" On the Museum Fund of the Russian Federation and museums in the Russian Federation "[7] guarantees citizens' access to Museum items and Museum collections included in the Museum Fund of the Russian Federation and located in museums in Russia. Access restrictions may be imposed only on the grounds provided for by the legislation of the Russian Federation, including due to the unsatisfactory state of preservation of Museum items and Museum collections, due to restoration work or the presence of a Museum item or Museum collection in the storage (Depository) of the Museum. Restriction of access to Museum items and collections for censorship reasons is not allowed (article 35).

Museum items are classified as cultural values that are restricted in circulation. In accordance with article 36 of the Federal law of 26.05. 1996 N 54-FZ "About Museum Fund of the Russian Federation and museums in Russian Federation" transfer of rights to commercial use of reproductions of Museum objects and Museum collections included in Museum Fund of the Russian Federation, and located in museums in the Russian Federation, is carried out by museums in the manner prescribed by the owner of Museum objects and Museum collections. The production of fine, printed, souvenir and other replicated products and 
consumer goods using images of Museum items and Museum collections, Museum buildings, objects located on the territories of museums, as well as using their names and symbols is carried out with the permission of the Museum directorates.

According to article 53 of the Basic legislation of the Russian Federation on culture, enterprises, institutions and organizations can produce and " sell products (including advertising) with the image (reproduction) of cultural objects and cultural heritage, cultural figures with the official permission of the owners and depicted persons. In accordance with article 1281 of the Civil Code of the Russian Federation, the exclusive right to a work is valid for the entire life of the author and seventy years, counting from January 1 of the year following the year of the author's death. After the termination of the exclusive right, a work of science, literature or art, whether published or unpublished, passes into the public domain (article 1282 of the Civil Code of the Russian Federation).

If a work of art becomes a Museum item, it is subject to a special legal regime, including the regime of its reproduction.

In this regard, in practice, there is a question about the legal regime of images of Museum objects used in business activities as a commodity (copies, reproductions, images on objects, etc.), that is, when reproductions of Museum objects are used commercially. When considering a case, the court must meet the requirements of reasonableness [8].

Thus, according to the claim of the "State Hermitage" to an individual entrepreneur to prohibit the latter from using in business activities without the appropriate permission the reproduction of Thomas Gainsborough's painting "the Lady in blue" ("Portrait of the Duchess of Beaufort"), the subject of the dispute was the requirement to prohibit commercial use of reproduction of an object from the Museum Fund of the Russian Federation. The courts applied the norms of the Museum legislation of the Russian Federation, which restrict the commercial use of reproductions of Museum collections and establish a special legal regime for such objects. It was proved that the entrepreneur violated the rights of the" State Hermitage " by using a controversial stylized drawing as the emblem of a clothing store. At the same time, there was no evidence of a contract for the commercial use of a reproduction of a Museum object included in the Museum Fund of the Russian Federation (T. Gainsborough's Portrait of a lady in blue (Duchess de Beaufort) or in any other legal way. The court concluded that the use of a reproduction of a picture (a stylized drawing similar to the picture to the extent of confusion) in the process of displaying a clothing collection is a commercial use, since such use is associated with advertising and is aimed at causing an unlimited number of people to 
associate the image of a picture with goods, the manufacturer and seller of which is an entrepreneur. (Ruling of the Supreme Court of the Russian Federation no. 308-ES15-6600 dated 06.07.2015) [9].

The right to participate in cultural life corresponds to the constitutional duty of everyone to take care of the preservation of historical and cultural heritage, to protect historical and cultural monuments. Federal law of June 25, 2002 N 73-FZ "On objects of cultural heritage (monuments of history and culture) of peoples of the Russian Federation" [10] is related to the cultural heritage of immovable property (including archaeological heritage) and other facilities with historically related territories, paintings, sculpture, decorative-applied art, objects of science and technology and other items of material culture resulting from historical events. Cultural heritage sites are evidence of epochs and civilizations, authentic sources of information about the origin and development of culture and, accordingly, are valuable in terms of history, archeology, architecture, urban planning, art, science and technology, aesthetics, Ethnology or anthropology, and social culture. Citizens of Russia are guaranteed the preservation of cultural heritage objects (article 7). Historical and cultural heritage, both tangible and intangible, is a repository of knowledge. Its protection must take place at the same time as economic development, since heritage, both tangible and intangible, is fragile and often unwittingly destroyed or lost in the rush of modernization. In order to prevent actions that may cause harm to cultural heritage objects (damage, destruction or destruction, changes in the appearance and interior, violation of the established procedure for use, illegal movement), as well as to protect against adverse environmental impacts and other negative impacts, cultural heritage objects are subject to state protection. The annual state report on the state of culture in the Russian Federation includes objective systematized analytical information on the state and state protection of cultural heritage objects (article 12.1).

The right to freedom of creative activity and protection of intellectual property, stipulated in article 44 of the Constitution of the Russian Federation, is directly related to the right of citizens, stipulated in article 34 of the Constitution of the Russian Federation, to freely use their abilities and property for entrepreneurial and other economic activities not prohibited by law. The constitutional provisions on freedom of business activity are developed in article 1 of the Civil Code of the Russian Federation, which is devoted to the main principles of civil legislation[11]. The Code recognizes the equality of participants, the inviolability of property, freedom of contract, the inadmissibility of arbitrary interference in private Affairs, the need for unhindered exercise of civil rights, and their judicial protection. Citizens (individuals) and legal 
entities acquire and exercise their civil rights by their will and in their interest. They are free to establish their rights and obligations on the basis of the contract and to determine any conditions of the contract that do not contradict the law. These constitutional rights correspond to the provisions of the Universal Declaration of Human Rights, which proclaims the right of everyone to protect the moral and material interests arising from any scientific, literary or artistic work of which he is the author.

\section{Conclusion}

As noted in the scientific literature, "the right to freedom of creative activity and protection of intellectual property provides an opportunity for entrepreneurs to use the results of scientific and technological progress for profit, having a guarantee that another person can not use intellectual property registered in accordance with the established procedure for the manufacture of goods or services without the consent of the rightholder"[12]. In this regard, it should be pointed out that the Federal law "On science and state scientific and technical policy" provides for the commercialization of scientific and technical results-activities to involve such results in economic turnover, as well as innovative projects-a set of measures to implement innovations. An innovative project is characterized by a high acceptable level of risk, the possibility of not achieving the planned result, including the economic effect of such a project. The main legal form of relations between a scientific organization, the customer and other consumers of scientific and (or) scientific and technical products are contracts for the creation, transfer and use of scientific and technical products, the provision of scientific, scientific and technical, engineering consulting and other services, as well as other agreements, including agreements on joint scientific and (or) scientific and technical activities and profit distribution.

\section{References}

1. Universal Declaration of Human Rights (adopted at the third session of the UN General Assembly by resolution 217 A (III) of December 10, 1948).

2. International Covenant on Civil and Political Rights (New York, December 16, 1966).

3. The Power of culture for development https://unesdoc.unesco.org/ark:/48223/pf0000189382

4. Law of the Russian Federation of October 9, 1992 N 3612-I "Fundamentals of legislation of the Russian Federation on culture" ed.01.04.20 
5.Federal law of August 23, 1996 N 127-FZ "On science and state scientific and technical policy" ed.31.07.20.

6. Federal law of August 22, $1996 \mathrm{~N} 126-\mathrm{FZ}$ "On state support of cinematography of the Russian Federation" ed. 28.11.2018.

7. Federal law of may 26, 1996 N 54-FZ "On the Museum Fund of the Russian Federation and museums in the Russian Federation" ed.28.03.2019.

8. Lebed K. A. Validity of a court decision in civil proceedings / / Humanities, socioeconomic and social Sciences. 2020. N 7. [Electronic resource] https://onlinescience.ru/m/products/law_sciense/gid5943/pg0/ (accessed 18.08.2020).

9. Ruling of the Supreme Court of the Russian Federation no. 308-ES15-6600 dated 06.07.2015).

10. Federal law of June 25, 2002 N 73-FZ "On objects of cultural heritage (historical and cultural monuments) of the peoples of the Russian Federation" ed.05.05.20.

11. BUSINESS LAW IN THE XXI CENTURY: ORIGINS AND PROSPECTS .Battakhov P. P., Budnikova Yu. E., Bulgakova L. I., Zankovsky S. S., Kleandrov M. I. Moscow, 2018.

12. Yakimova E. M. The concept of equilibrium of the system of constitutional regulation of business activity. - Moscow: "Justicinform", 2020. - 320 p. [Electronic resource] SPS "Garant" (accessed 20.08.2020). 